\title{
The Evaluation of a Website for Participatory Water Quality Monitoring of Rivers in Indonesia
}

\author{
Eka Sulistiyowati ${ }^{1, *}$ Shofwatul Uyun ${ }^{2}$ \\ ${ }^{1}$ Department of Biology, Faculty of Science and Technology, UIN Sunan Kalijaga, Yogyakarta, Indonesia \\ ${ }^{2}$ Department of Informatics, Faculty of Science and Technology, UIN Sunan Kalijaga, Yogyakarta, Indonesia \\ ${ }^{*}$ Corresponding author. Email: eka.sulistiyowati@uin-suka.ac.id
}

\begin{abstract}
The research on developing a water monitoring website had been conducted in the Integrated Laboratory UIN Sunan Kaliljaga, Yogyakarta. The output of this research a website titled (www.statusmutuair.com). In this paper, we evaluate the website by involving the community as the users. The community then used the website to input the data from the water quality measurements conducted directly. Three communities have represented Kambaniru River in East Sumba, Gajah Wong River in Yogyakarta, and Brantas River in East Java. We analyse the users' and administrators' perceptions using a simple questionnaire. The data were then presented descriptively. The result showed that based on the users' perception, the application meets the criteria of ease of access, data display, and reporting.
\end{abstract}

Keywords: monitoring, participatory, perceptions, water quality, website.

\section{INTRODUCTION}

The cumulative effects of urbanization, population growth, and unsupervised wastewater disposal continue to exacerbate water pollution in inland water and rivers [1]. It was reported that big cities of Indonesia, such as Yogyakarta, experience low-quality water resources because it only has a limited wastewater disposal infrastructure. Overall, sanitation status in this area is relatively very poor. Poor sanitation and low water quality have created incidents of waterborne diseases such as diarrhoea [2]. This water and sanitation profile does not only occur in Yogyakarta. Other cities such as Surabaya (East Java) [3] and Jakarta (the capital city of Indonesia) [4] report a similar situation.

At the same time, water quality assessment remains a big problem in developing countries [5]. Technical problems such as the number of parameters involved in the water quality guidelines, the number of laboratories available for testing, and human resources capacities in handling samples are the three most common problems in Indonesia. River water quality monitoring in its action is not an easy task that involves a significant number of parameters and is challenged by the vastness of the studied area. These two challenges imply a considerable investment in laboratory analysis and laborious work in data collection. Public participation, therefore, becomes an increasing trend in water quality monitoring worldwide, as has been stressed by the United Nations Environment Programme (UNEP). UNEP recognizes that participatory public participation in any ecological monitoring actions is an essential aspect of sustainable development. However, in a budget-cut country, such as Indonesia, there are significant gaps in water monitoring activities. Coupled with the vastness of areas to be monitored, a limited capacity of human resources, and limited equipment, water quality monitoring is a complex problem at its peak.

Another challenge for Indonesia is that the policy instrument for measuring water quality has just been released in 2003 [6], long after the concept of the Water Quality Index (WQI) -as the early document in water quality monitoring- was released in the 1990s. It shows that the Ministry of Environment is relatively late in issuing water quality instruments, although the document of Decree No. 81/2003 completely adopts the readily available Water Pollution Index (WPI) and Storet Index.

Water quality monitoring has been widely discussed in literature based on various issues, such as water quality [7] and the development of monitoring systems using computation [8] [9] [10] and satellite images [11]. Some studies discuss the use of WQI [12] [13] for water quality monitoring. Also, the use of low-cost water quality monitoring has been explored by [14] [15] [16]. 
However, in Indonesia, water quality monitoring using a simple water quality index is not yet studied

Although the work for water quality monitoring has been conducted widely by some authorities, most of the results does not readily available and publicly accessible. ICEL, for example, is an independent organization that commits to the actions for preventing pollution and monitoring the status of water quality in Indonesia. The website of ICEL, http://spektakel.id/icel/peta/, provides data for water quality only for four years (2012-2015). It indicates that ICEL faces obstacles in data update and maintenance. Another limitation of ICEL is that it only generates an overall conclusion for each river, yet water pollution may occur in the segmented area. Thus, ICEL cannot portray it.

Understanding that water quality monitoring has been a difficult issue, we developed a website, titled www.statusmutuair.com, that enables the wider public to participate in the monitoring process. The whole process for website development and the computing techniques was documented and discussed in [17]-[19]. As a follow up of those works, this study aimed at evaluating the usefulness of the website by the users.

\section{METHODS}

The first step in this research is the development of the Web-based Platform for River Health Assessment. To do this, we create a website (www.statusmutuair.com) as our platform. There are several parameters of water quality that need to be measured participatory by the communities involved in the water monitoring project. The parameters are water temperature, TDS, EC, DO, BOD, and coliform.

After the website is developed, we test the website's usability in three communities represented by three major rivers in three cities. The major concept in this research is the involvement of the community in collecting and inputting the data. Three communities from three rivers, Kambaniru River in Nusa Tenggara Timur, Brantas River in East Java, and Gajah Wong River in Yogyakarta, are chosen to participate in monitoring water quality actively. The concept was then developed into an application, and the community participated in data collection and input.

Next, the application calculated and concluded the water quality status of the locations. The water quality status was measured using the STORET method as recommended by the Government Regulation N0. $82 / 2001$

At this phase, the research team actively accompanied the community in the data gathering process and provided education about water quality status. In this research, we worked with the community of Brantas River (Brantas Berdaya) and Gajah Wong (Forsidas
Gajahwong). However, for Kambaniru River, since there was no such an established community, we worked with the community of Paluanda Lama Hamu -a community that was established as an organization to conserve tenun ikat (traditionally woven fabric). Generally, we applied the following concept (Fig. 1).

The participants' perceptions were then studied by administering a simple questionnaire based on three criteria: ease of access, display, and reporting. The overall process of studying the perceptions modifies research conducted by [15].

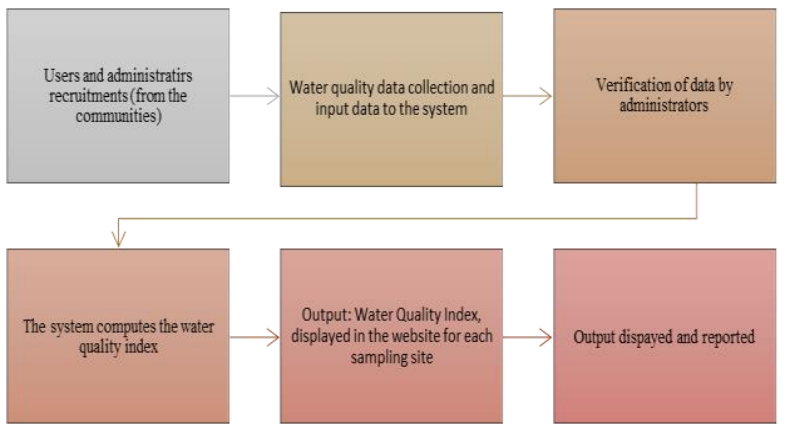

Figure 1. The general concept of participatory water quality monitoring using a website and involving communities of rivers in Indonesia

The overall data collection process was five months, including developing the website, engaging with the community, water analysis, and evaluation of the website by the engaged communities. The website and software involved in this research were initially developed in the Integrated Laboratory UIN Sunan Kalijaga, Yogyakarta.

\section{RESULT AND DISCUSSION}

First, we invited the volunteers from the communities to measure water quality using several parameters. We train the volunteers how to use on-site water test kits and collect the data. We only use simple water parameters obtained on-site, and no need for laborious technical works. The table below is an example of how the community put the data into the table.

Table 1. Water quality data taken by the communities in Kambaniru, Gajahwong, and Brantas

\begin{tabular}{|c|c|c|c|c|}
\hline Parameter & Unit & $\begin{array}{c}\text { Kamba } \\
\text { niru }\end{array}$ & $\begin{array}{c}\text { Gajah } \\
\text { wong }\end{array}$ & Brantas \\
\hline Temperature & ${ }^{\circ} \mathrm{C}$ & 29 & 28,4 & 28,4 \\
\hline $\mathrm{EC}$ & $\mathrm{mhos} / \mathrm{cm}$ & 314 & 292 & 310 \\
\hline $\mathrm{TDS}$ & $\mathrm{mg} / \mathrm{L}$ & 157 & 156 & 156 \\
\hline $\mathrm{pH}$ & & 7,7 & 7,5 & 7,4 \\
\hline $\mathrm{DO}$ & $\mathrm{mg} / \mathrm{L}$ & 6,1 & 4,75 & 6 \\
\hline $\mathrm{BOD}$ & $\mathrm{mg} / \mathrm{L}$ & 6,22 & 7,9 & 13,83 \\
\hline Coliform & $\mathrm{MPN} / 100 \mathrm{ml}$ & 93 & 150 & 460 \\
\hline
\end{tabular}


Users and administrators evaluate the application. The number of users is 16 for each river, so there are in total 48 users. And, the number of administrators are two for each river, with a total of six administrators for all. We evaluate the system's usability based on three criteria: ease of access and data input, data display, and reporting. In terms of ease of access, the application gained a score between $69.79 \%-77.08 \%$. The highest score for ease of access and data input is gained from users in Brantas, followed by users in Gajah Wong and Kambaniru. A similar pattern could be examined from two other criteria. Users in Brantas gained the highest score in terms of data display and reporting (figure 1).

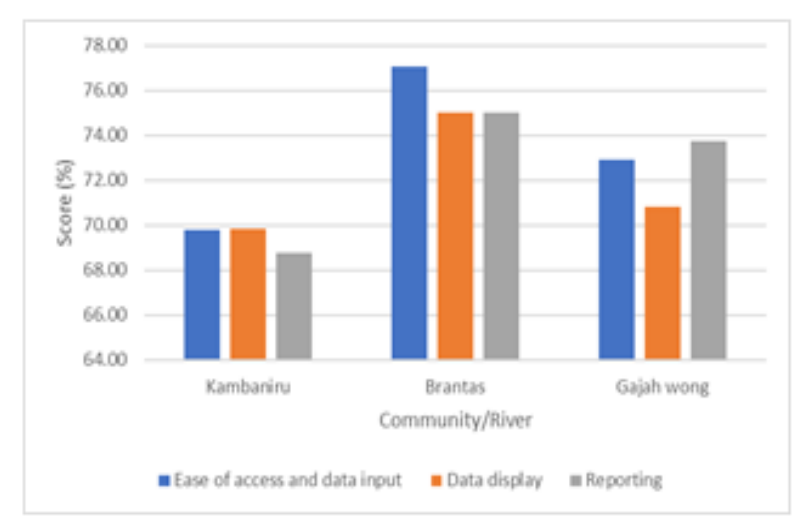

Figure 2. The users' perception of the system based on three criteria

The trend in figure 2 could readily tell that if the application is used by the urban community, such as in Brantas and Gajahwong, the users may find that it meets the criteria of ease of access, data display, and reporting. The only rural community involved in this research, the Kambaniru river community, sees some difficulties operating the application. It may be due to the limitation of internet connection and access to technology that is not always available in Kambaniru.

Analysis of each criterion for each criterion shows that in terms of ease of access, the highest score was temporary data saving and data updating for saved data. It implies that the users find the features of temporary data saving are essential.
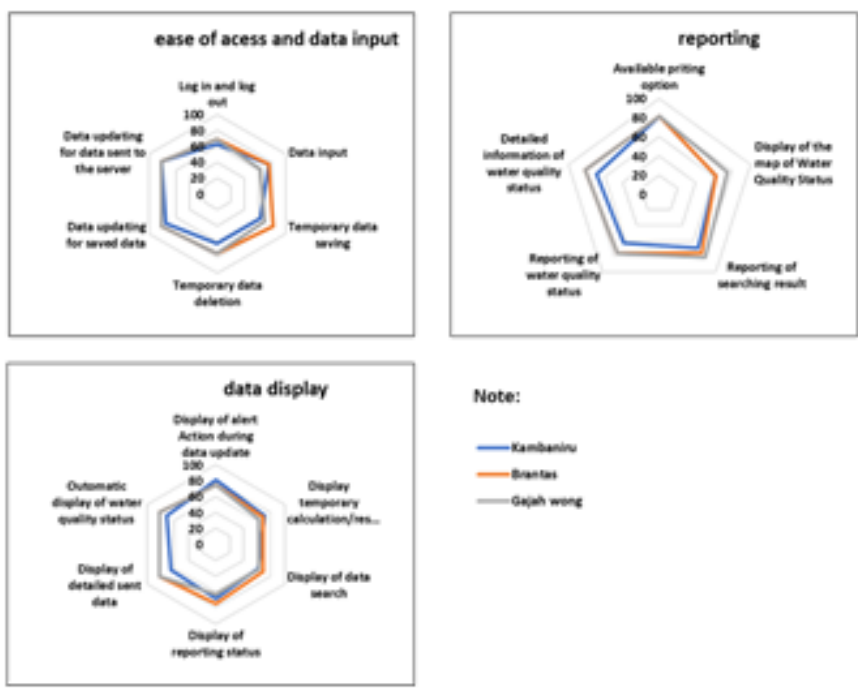

Note:

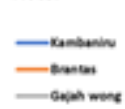

Figure 3. Radar diagram for the individual indicator of the users' perception of the developed application.

Further, as shown in figure 2 , users see that data display is necessary for a website. Hence they gave a high score for the menus, such as automatic display of water quality status and reporting status. Lastly, in terms of reporting, the highest score is achieved in the availability of the printing option. It seems that users prefer to see their results on paper as complementary to a result displayed online

Next, we conducted administrators' evaluations based on qualitative interviews with them. The administrators mentioned several points. First, in terms of display, the administrators think it could be improved by having an "interesting display". An interesting display may increase users' participation, moreover, if it has an Android option for the application. Second, our prototype only allows the monitoring of three rivers. Hence administrators see the importance to expand to many other rivers in Indonesia. Also, it is necessary to include terrestrial water reservoirs such as lakes and streams because water quality in these types of reservoirs is no less important.

\section{CONCLUSION}

We evaluated a website (www.statusmutuair.com) for participatory water quality monitoring system based on real-time calculation. The users and administrator evaluated the application. The result shows that the users find the system could meet the ease of access, data display, and reporting. Further improvement could be made in terms of "interesting display" and expanding the system to other rivers in Indonesia. Further development to improve the website is required including accommodating the interface and data collection issues 


\section{ACKNOWLEDGMENTS}

We thank Lembaga Penelitian dan Pengabdian Pada Masyarakat (LPPM) UIN Sunan Kalijaga for the funding of this research. We acknoewlede the communities of Kambaniru, Gajah Wong, and Brantas for participating during gata gathering and the product's evaluation

\section{REFERENCES}

[1] K. Bostoen, P. Kolsky, and C. Hunt, "Improving Water and Sanitation Services: Health, Access, and Boundaries," in Scalling Urban Environmental Challenges from Local to Global and Back, P. J. Marcotulio and G. McGranahan, Eds. UK: Routledge, 2007.

[2] B. Salendu, "Quality assessment and interrelations of water supply and sanitation: a case study of Yogyakarta City, Indonesia," Thesis, International Institute For Geo-Information Science And Earth Observation Enschede, The Netherlands, The Netherlands, 210AD.

[3] A. Hayati et al., "Alfiah Hayati and Nureka Tiantono and Muhamad Water quality and fish diversity in the Brantas River, East Java, Indonesia.," Hayati: Journal of Biological Researches, vol. 22, no. 2, pp. 43-49, 2017.

[4] A. M. Vollaard et al., "A Survey of the Supply and Bacteriologic Quality of Drinking Water and Sanitation in Jakarta, Indonesia," Southeast Asian J TROP MED PUBLIC HEALTH, vol. 36, no. 6, p. 10, 2005.

[5] S. Abbaspour, "Water Quality in Developing Countries, South Asia, South Africa, Water Quality Management and Activities that Cause Water Pollution," in International Proceedings of Chemical, Biological and Environmental Engineering (IPCBEE), Singapore, 2011, vol. 15, pp. 94-102.

[6] Kementrian Lingkungan Hidup, "Keputusan Menteri Negara Lingkungan Hidup Nomor 115 Tentang Pedoman Penentuan Status Mutu Air,." Kementrian Lingkungan Hidup, 2003.

[7] E. Budiyanto, Sistem Informasi Geografis Menggunakan Arcview GIS. Yogyakarta, Indonesia: Penerbit Andi, 2002.

[8] H. Effendi, Telaah kualitas air, bagi pengelolaan sumber daya dan lingkungan perairan. Yogyakarta, Indonesia: Kanisius, 2003.

[9] R. Ekawati and U. Suprihadi, "Analysis of S2 (Spherical) Geometry Library Algorithm for GIS Geocoding Engineering," Teknomnika, vol. 16, no. 1, pp. 334-342, 2018
[10] Q. Khotimah, W. F. Mahmudy, and V. N. Wijayaningrum, "Optimization of Fuzzy Tsukamoto Membership Function using Genetic Algorithm to Determine the River Water," International Journal of Electrical and Computer Engineering, vol. 7, no. 5, pp. 2838-2846., 2017.

[11] Y. B. Sulistioadi et al., "Satellite radar altimetry for monitoring small rivers and lakes in Indonesia," Hydrology and Earth System Sciences, vol. 19, no. 1, pp. 341-359, 2015, doi: 10.5194/hess-19-3412015.

[12] A. D. Sutadian, N. Muttil, and A. G. Yilmaz, "Development of a water quality index for rivers in West Java Province, Indonesia," Ecol. Indic., vol. 85, pp. 966-982, 2018.

[13] M. Bora and D. C. Goswami, "Water quality assessment in terms of water quality index (WQI): case study of the Kolong River, Assam, India," Appl. Water Sci., vol. 7, no. 6, pp. 3125-3135, 2016.

[14] T. Thatoe Nwe Win, T. Bogaard, and N. van de Giesen, "A Low-Cost Water Quality Monitoring System for the Ayeyarwady River in Myanmar Using a Participatory Approach,"Water, vol. 11, no. 10, p. 1984, Sep. 2019, doi: 10.3390/w11101984.

[15] A. Jonoski, A. Almoradie, K. Khan, I. Popescu, and S. J. van Andel, "Google Android mobile phone applications for water quality information management," Journal of Hydroinformatics, vol. 15, no. 4, pp. 1137-1149, Oct. 2013, doi: 10.2166/hydro.2012.147.

[16] N. J. Wilson, E. Mutter, J. Inkster, and T. Satterfield, "Community-Based Monitoring as the practice of Indigenous governance: A case study of Indigenousled water quality monitoring in the Yukon River Basin," Journal of Environmental Management, vol. 210, pp. 290-298, 2018.

[17] S. Uyun, "Geographic Information System for a Community-Based Water Quality Mapping of Rivers in Indonesia. Kinetik," Kinetik, vol. 5, no. 3, pp. 219-225, 2020.

[18] S. Uyun, R. S. A. Ayubi, and Y. S. Ambarwati, "Pengembangan Sistem Pemetaan Status Mutu Air Sungai Berbasis Web Menggunakan Extreme Programming," JISKA, vol. 4, no. 3, pp. 173-184, 2020 .

[19] S. Uyun and E. Sulistiyowati, "Feature selection for multiple water quality status: integrated bootstrapping and SMOTE approach in imbalance classes," International Journal of Electrical and Computer Engineering, vol. 10, no. 4, pp. 43314339, 2019. 